\title{
Polymerization of Acetylenes Containing Heptadecafluorononenyloxy Group and Polymer Properties
}

\author{
Toshio Yoshimura* and Masaya Asano \\ Electronic and Imaging Materials Research Laboratories, \\ Toray Industries Inc., 1-2, Sonoyama 3-chome, \\ Otsu, Shiga 520, Japan
}

(Received June 7, 1993)

\begin{abstract}
Polymerizations of two kinds of fluorine-containing aromatic disubstituted acetylenes, 1-[p-(heptadecafluorononenyloxy)phenyl $]-2-$ phenylacetylene $\left(p-\mathrm{C}_{9} \mathrm{~F}_{17} \mathrm{ODPA}\right)$ and 1 - $\left[p\right.$-(heptadecafluorononenyloxy)phenyl]-1-hexyne $\left(p-\mathrm{C}_{9} \mathrm{~F}_{17} \mathrm{OPH}\right)$ were studied with groups 5 and 6 transition-metal catalysts. $p-\mathrm{C}_{9} \mathrm{~F}_{17} \mathrm{ODPA}$ polymerized with $\mathrm{TaCl}_{5}-\mathrm{Et}_{3} \mathrm{SiH}$ catalyst to give a new polymer over 70 yield and its maximum intrinsic viscosity $([\eta])$ was as high as $2.1 \mathrm{dlg}^{-1}$. $p-\mathrm{C}_{9} \mathrm{~F}_{17} \mathrm{OPH}$ polymerized with $\mathrm{Ta}$ and $\mathrm{Nb}$ catalysts, but yield and $[\eta]$ of the polymer were lower. $\operatorname{Poly}\left(p-\mathrm{C}_{9} \mathrm{~F}_{17} \mathrm{ODPA}\right)$ and $\operatorname{poly}\left(p-\mathrm{C}_{9} \mathrm{~F}_{17} \mathrm{OPH}\right)$ were in the form of a yellow solid and white solid, and began to lose weight at $410^{\circ} \mathrm{C}$ and $270^{\circ} \mathrm{C}$, respectively, which indicates high thermal stability. Both polymers had a main-chain structure consisted of alternating double bonds, and were completely soluble in some fluorine-containing solvents such as $m-\left(\mathrm{CF}_{3}\right)_{2} \mathrm{C}_{6} \mathrm{H}_{4}$ and $\mathrm{CCl}_{2} \mathrm{FCClF}_{2}$. Poly $\left(p-\mathrm{C}_{9} \mathrm{~F}_{17} \mathrm{ODPA}\right)$ formed a tough film by solution casting, and showed high $P_{\mathrm{O}_{2}}$ value $\left[4 \times 10^{-8} \mathrm{~cm}^{3}\right.$ (STP) $\left.\mathrm{cm} \mathrm{cm}^{-2} \mathrm{~s}^{-1} \mathrm{~cm} \mathrm{Hg}^{-1}\right]$ comparable to that of poly(dimethylsiloxane).

KEY WORDS Substituted Acetylene / Transition-Metal Catalyst / Metathesis Polymerization / Fluorine-Containing Polymer / Gas Permeability /
\end{abstract}

The polymerization of various substituted acetylenes has been achieved by Masuda and Higashimura with catalysts based on groups 5 and 6 transition-metals. ${ }^{1,2}$ Among them, polymers of aromatic disubstituted acetylenes show fairly high thermal stability. ${ }^{3}$ The on-set temperatures of weight loss of poly(diphenylacetylene $)^{4}$ [poly(DPA)] and poly(1-phenyl1-alkynes), ${ }^{5,6}$ which are repesentative aromatic disubstituted hydrocarbon polymers, are $500^{\circ} \mathrm{C}$ and around $300^{\circ} \mathrm{C}$, respectively.

Fluorine-containing polyacetylenes are expected to show unique properties and functions because they have unique structures of alternating double-bonds in the main chain and fluorine atoms in the side group. Several fluorine-containing acetylenes have been polymerized. Most, however, are aliphatics or monosubstituted aromatics, whose recent examples include; $\mathrm{HC} \equiv \mathrm{CC}_{6} \mathrm{~F}_{13}{ }^{7}$ (intrinsic viscosity $\left.[\eta] \quad 0.05 \mathrm{dlg}^{-1}\right), \quad \mathrm{HC} \equiv \mathrm{CC}_{6} \mathrm{H}_{4}-o-$ $\mathrm{CF}_{3}{ }^{8,9}$ [weight-average molecular weight $\left(\bar{M}_{w}\right)$ $\left.\sim 1 \times 10^{6}\right], \quad \mathrm{HC} \equiv \mathrm{CC}_{6} \mathrm{H}_{3}-2,4-\left(\mathrm{CF}_{3}\right)_{2}{ }^{10} \quad([\eta]$ $\left.0.35 \mathrm{dlg}^{-1}\right), \quad \mathrm{HC} \equiv \mathrm{CC}_{6} \mathrm{~F}_{5}{ }^{11}\left([\eta] 0.6 \mathrm{dlg}^{-1}\right)$, $\mathrm{HC} \equiv \mathrm{CC}_{6} \mathrm{~F}_{4}-p-\mathrm{C}_{4} \mathrm{H}_{9}{ }^{11} \quad\left(\bar{M}_{w} \quad \sim 2 \times 10^{6}\right)$, $\mathrm{CH}_{3} \mathrm{C} \equiv \mathrm{CC}_{6} \mathrm{~F}_{5}{ }^{12}$ (insoluble).

1-[p-(Heptadecafluorononenyloxy)phenyl]2-phenylacetylene $\left(p-\mathrm{C}_{9} \mathrm{~F}_{17} \mathrm{ODPA}\right)$ and 1 -[p-(heptadecafluorononenyloxy)phenyl]1-hexyne $\left(p-\mathrm{C}_{9} \mathrm{~F}_{17} \mathrm{OPH}\right)$ are new fluorinecontaining aromatic disubstituted acetylenes. They are derivatives of diphenylacetylene (DPA) and 1-phenyl-1-hexyne (PH), and are featured by high fluorine content. Thus it is of interest to study their polymerization behavior and properties.

\footnotetext{
* To whom correspondence should be addressed.
} 
The present paper deals with the polymerization of $p-\mathrm{C}_{9} \mathrm{~F}_{17} \mathrm{ODPA}$ and $p-\mathrm{C}_{9} \mathrm{~F}_{17} \mathrm{OPH}$. Soluble, high molecular weight polymers have been successfully obtained from $p-\mathrm{C}_{9} \mathrm{~F}_{17} \mathrm{OD}$ $\mathrm{PA}$ and $p-\mathrm{C}_{9} \mathrm{~F}_{17} \mathrm{OPH}$, and the structures and properties of the polymers have been clarified.

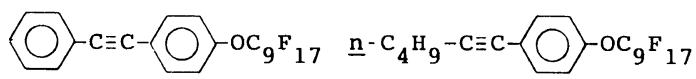

$$
\begin{aligned}
& \text { p- } \mathrm{C}_{9} \mathrm{~F}_{17} \text { ODPA } \quad \text { p- } \mathrm{C}_{9} \mathrm{~F}_{17} \mathrm{OPH}
\end{aligned}
$$

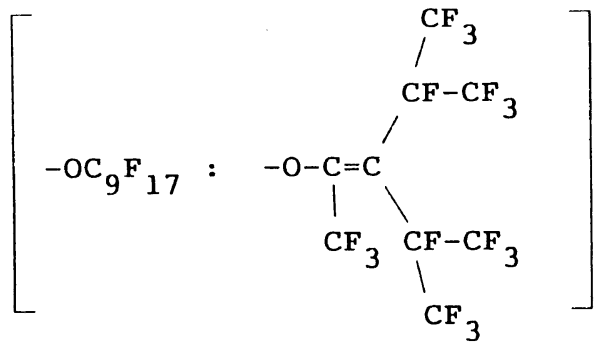

\section{EXPERIMENTAL}

\section{Monomer Synthesis}

$p-\mathrm{C}_{9} \mathrm{~F}_{17} \mathrm{ODPA}$ and $p-\mathrm{C}_{9} \mathrm{~F}_{17} \mathrm{OPH}$ were prepared with reference to the literature ${ }^{13,14}$ according to the following scheme:

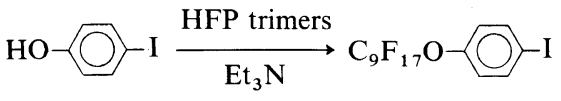

(I)

$$
\begin{array}{r}
\underset{\mathrm{Pd} \text { cat }}{\stackrel{\mathrm{HC} \equiv \mathrm{C}-\mathrm{R}}{\longrightarrow}} \mathrm{C}_{9} \mathrm{~F}_{17} \mathrm{O}-\mathrm{O}-\mathrm{C} \equiv \mathrm{C}-\mathrm{R} \\
\left(\mathrm{R}=\mathrm{Ph}, n-\mathrm{C}_{4} \mathrm{H}_{9}\right)
\end{array}
$$

Compound (I) and monomers are new materials. As an example, the procedure for synthesizing $p-\mathrm{C}_{9} \mathrm{~F}_{17} \mathrm{ODPA}$ is described in detail.

$p$-(Heptadecafluorononenyloxy)iod obenzene (I): $p$-Iodophenol $(53 \mathrm{~g}, 0.24 \mathrm{~mol})$, hexafluoropropene trimers [a mixture of octadecafluoro-3-ethyl-2,4-dimethyl-2-pentene and octadecafluoro-3-(1-methylethyl)-4-methyl-2pentene; $113 \mathrm{~g}, 0.25 \mathrm{~mol}$, and dimethylacetamide $(250 \mathrm{ml})$ were placed in a $1-1$ beaker. To this mixture, triethylamine $(35 \mathrm{ml}, 0.25 \mathrm{~mol})$ was added dropwise keeping the mixture below $20^{\circ} \mathrm{C}$. After stirring for $3 \mathrm{~h}$ at room temparature, the mixture was poured into 2 liters of diluted hydrochloric acid. The separated solid was diluted with dichloromethane and washed with $5 \%$ sodium hydroxide solution, and then water. The organic phase was dried over anhydrous sodium sulfate overnight and dichloromethane was evaporated. The crude product was recrystallized from ethanol to afford a colorless solid (I), $\mathrm{mp} 45^{\circ} \mathrm{C}$, yield $82 \%$.

$p-\mathrm{C}_{9} \mathrm{~F}_{17} \mathrm{ODPA}$ : After flushed with nitrogen, a 1-1 flask was charged with dry triethylamine $(200 \mathrm{ml}),\left(\mathrm{Ph}_{3} \mathrm{P}\right) \mathrm{PdCl}_{2}(0.14 \mathrm{~g}, 0.2$ $\mathrm{mmol}), \mathrm{CuI}(0.23 \mathrm{~g}, 1.2 \mathrm{mmol}), \mathrm{Ph}_{3} \mathrm{P}(0.21 \mathrm{~g}, 0.8$ $\mathrm{mmol})$, and phenylacetylene $(20 \mathrm{ml}, 0.18 \mathrm{~mol})$, and the mixture was stirred at room temperature for $1 \mathrm{~h}$. A solution of $p$-(heptadecafluorononenyloxy)iodobenzene $(97 \mathrm{~g}, 0.15 \mathrm{~mol})$ in triethylamine $(200 \mathrm{ml})$ was added, and the mixture was heated at $60^{\circ} \mathrm{C}$ for $3 \mathrm{~h}$ with stirring. After completation of the reaction was confirmed by gas chromatography (GC), the mixture was poured into 1 liter of $5 \%$ hydrochloric acid. The mixture was extracted with dichloromethane, the organic phase was dried over anhydrous sodium sulfate overnight, and dichloromethane was evaporated. The crude product was recrystallized from methanol to give pure $p-\mathrm{C}_{9} \mathrm{~F}_{17} \mathrm{ODPA}$ as a colorless solid, $\mathrm{mp} 105^{\circ} \mathrm{C}$, yield $67 \%$, purity $>99 \%$ (GC). The structure of the heptadecafluorononenyloxy group of $p-\mathrm{C}_{9} \mathrm{~F}_{17} \mathrm{ODPA}$ was confirmed by ${ }^{19} \mathrm{~F}$ NMR spectrum (chemical shift, $\delta$, ppm from $\mathrm{CFCl}_{3}$ in $\mathrm{CDCl}_{3}$ ); $-56.9(\mathrm{~d}, 3 \mathrm{~F}),-72.0(\mathrm{~s}, 6 \mathrm{~F}),-73.1(\mathrm{~d}, 6 \mathrm{~F})$, $-168.2(\mathrm{q}, 1 \mathrm{~F}),-170.2(\mathrm{~m}, 1 \mathrm{~F})$.

$p-\mathrm{C}_{9} \mathrm{~F}_{17} \mathrm{OPH}$ was prepared from (I) and 1-hexyne in the same way; the product was sticky oil and purified by distillation, bp $129^{\circ} \mathrm{C} / 3 \mathrm{mmHg}$, yield $67 \%$, purity $98 \%$ (GC), $d_{4}^{20} 1.479$.

\section{Catalyst Preparation and Polymerization}

Transition-metal chlorides and organome- 
tallic cocatalysts were commercially obtained and used without further purification. Care was taken that they would not be decomposed by moisture and/or air. Solvents for polymerization were purified by the standard methods.

Polymerizations were performed in prebaked glass vessels under dry nitrogen. The following polymerization procedure is exemplary (see Table III, no. 3 for the result): In a Schlenk tube equipped with a three-way stopcock, a monomer solution was prepared by mixing $p-\mathrm{C}_{9} \mathrm{~F}_{17}$ ODPA $(1.5 \mathrm{mmol}, 0.94 \mathrm{~g})$, 1,2,4-trichlorobenzene $(0.20 \mathrm{ml}$; internal standard for GC) and $\mathrm{PhCl}(2.17 \mathrm{ml})$. In another Schlenk tube, $\mathrm{TaCl}_{5}(0.10 \mathrm{mmol}, 36 \mathrm{mg})$ and $\mathrm{Et}_{3} \mathrm{SiH}(0.20 \mathrm{mmol}, 23 \mathrm{mg})$ were dissolved in $\mathrm{PhCl}(3.0 \mathrm{ml})$, and the catalyst solution was aged at $80^{\circ} \mathrm{C}$ for $15 \mathrm{~min} .2 .0 \mathrm{ml}$ of the monomer solution were added to the catalyst solution. After polymerization at $80^{\circ} \mathrm{C}$ for $24 \mathrm{~h}$, the reaction was quenched by adding a mixture (5 ml) of $m-\left(\mathrm{CF}_{3}\right)_{2} \mathrm{C}_{6} \mathrm{H}_{4}$ and methanol (4:1 vol ratio). Monomer conversion was determined by GC (silicone DC550 $3 \mathrm{~m}, 170^{\circ} \mathrm{C}$ ). The reaction mixture was diluted with $m-\left(\mathrm{CF}_{3}\right)_{2} \mathrm{C}_{6} \mathrm{H}_{4}$ $(30 \mathrm{ml})$, and poured into acetone (1 liter) under stirring. The precipitated polymer was washed with acetone, filtered, and dried to a constant weight. Polymer yield was determined by gravimetry.

\section{Characterization}

Intrinsic viscosities $([\eta])$ of polymers were measured in $m$ - $\left(\mathrm{CF}_{3}\right)_{2} \mathrm{C}_{6} \mathrm{H}_{4}$ at $30^{\circ} \mathrm{C}$ using a Ubbelohde-type viscometer in the concentration (c) range $0.1-0.4 \mathrm{~g} \mathrm{dl}^{-1}$. Plots of $\eta_{\mathrm{sp}} / c v s$. $c$ were all linear.

${ }^{13} \mathrm{C}$ NMR spectra were observed with a JEOL EX270 spectrometer. ${ }^{19} \mathrm{~F}$ NMR spectrum of $p-\mathrm{C}_{9} \mathrm{~F}_{17} \mathrm{ODPA}$ monomer was measured at Toray Research Center, Inc. IR spectra and UV-visible spectra were recorded with a JASCO IR700 and Shimadzu UV160A spectrophotometer, respectively. Thermogravimetric analysis (TGA) was conducted with a Seiko TG/DTA200 thermal analyzer (in air, heating rate $\left.10^{\circ} \mathrm{Cmin}^{-1}\right)$. Contact angles of water and $n$-decane on $\operatorname{poly}\left(p-\mathrm{C}_{9} \mathrm{~F}_{17} \mathrm{ODPA}\right)$ were measured with Kyowa CA-D goniometer at $25^{\circ} \mathrm{C}$.

\section{RESULTS AND DISCUSSION}

\section{Polymerization of $p-C_{9} F_{17} O D P A$}

Table I shows the results for the polymerization of $p-\mathrm{C}_{9} \mathrm{~F}_{17} \mathrm{ODPA}$ by groups 5 and 6 transition-metal catalysts, which are effective for the polymerization of various substituted acetylenes. Use of $\mathrm{TaCl}_{5}$ alone as catalyst afforded only acetone-soluble products (acetone was employed as a precipitant instead of methanol which is often used, because unreacted $p-\mathrm{C}_{9} \mathrm{~F}_{17} \mathrm{ODPA}$ monomer also precipitated in methanol). When a two-fold amount of $n-\mathrm{Bu}_{4} \mathrm{Sn}$ to $\mathrm{TaCl}_{5}$ was employed as cocatalyst, acetone-insoluble poly $\left(p-\mathrm{C}_{9} \mathrm{~F}_{17} \mathrm{ODPA}\right)$ was obtained in a $70 \%$ yield. Since the polymers formed were soluble only in fluorinecontaining solvents, their molecular weights were estimated from $[\eta]$ in $m-\left(\mathrm{CF}_{3}\right)_{2} \mathrm{C}_{6} \mathrm{H}_{4}$. $[\eta]$ of the polymer was $c a .0 .9 \mathrm{dl} \mathrm{g}^{-1}$.

The corresponding $\mathrm{Nb}, \mathrm{W}$, and Mo catalysts induced the reaction of $p-\mathrm{C}_{9} \mathrm{~F}_{17} \mathrm{ODPA}$ to some extent, but polymer yields were zero or negligible; the acetone-soluble products were linear oligomers according to gel permeation

Table I. Polymerization of $p-\mathrm{C}_{9} \mathrm{~F}_{17} \mathrm{ODPA}$ by various catalysts ${ }^{\mathrm{a}}$

\begin{tabular}{lcccc}
\hline \multirow{1}{*}{ Catalyst } & Conversion & & \multicolumn{2}{c}{ Polymer $^{\mathbf{b}}$} \\
\cline { 2 - 2 } & $\%$ & & Yield $/ \%$ & {$[\eta] / \mathrm{dl} \mathrm{g}^{-1 \mathrm{c}}$} \\
\hline $\mathrm{TaCl}_{5}$ & 68 & & 0 & \\
$\mathrm{TaCl}_{5}-n-\mathrm{Bu}_{4} \mathrm{Sn}$ & 100 & & 70 & 0.87 \\
$\mathrm{NbCl}_{5}$ & 3 & & 0 & \\
$\mathrm{NbCl}_{5}-n-\mathrm{Bu}_{4} \mathrm{Sn}$ & 37 & & 8 & \\
$\mathrm{WCl}_{6}-n-\mathrm{Bu}_{4} \mathrm{Sn}$ & 58 & & 7 & \\
$\mathrm{MoCl}_{5}-n-\mathrm{Bu}_{4} \mathrm{Sn}$ & 26 & & 0 & \\
\hline
\end{tabular}

a Polymerized in toluene at $80^{\circ} \mathrm{C}$ for $24 \mathrm{~h}$; [M $]_{0}=0.20$ $\mathrm{M},[\mathrm{Cat}]=20 \mathrm{mM},\left[n-\mathrm{Bu}_{4} \mathrm{Sn}\right]=40 \mathrm{mM}$.

b Acetone-insoluble part.

c Intrinsic viscosity measured in $m-\left(\mathrm{CF}_{3}\right)_{2} \mathrm{C}_{6} \mathrm{H}_{4}$ at $30^{\circ} \mathrm{C}$. 
chromatography (GPC) and IR spectroscopy. These results show that the polymerization behavior of $p-\mathrm{C}_{9} \mathrm{~F}_{17} \mathrm{ODPA}$ is similar to that of DPA. ${ }^{4}$ Hence, the effect of reaction conditions was examined in detail using $\mathrm{TaCl}_{5^{-}}$ based catalyst, aiming at increased polymer molecular weight.

Effects of solvents were studied with use of $\mathrm{TaCl}_{5}-n-\mathrm{Bu}_{4} \mathrm{Sn}$ catalyst (Table II). When polymerization was carried out in $\mathrm{PhCl}$, both polymer yield and $[\eta]$ somewhat increased, compared with those obtained in toluene. On the other hand, some fluorine-containing solvents such as $\mathrm{PhCF}_{3}, m-\left(\mathrm{CF}_{3}\right)_{2} \mathrm{C}_{6} \mathrm{H}_{4}$ and $\mathrm{CCl}_{2} \mathrm{FCCl}_{2} \mathrm{~F}$ considerably decreased both. These results are probably due to low solubility of the catalyst in fluorine-containing solvents. Consequently, $\mathrm{PhCl}$ is a suitable solvent for polymerization of the present monomer.

Table III details effects of organometallic cocatalysts in the polymerization by $\mathrm{TaCl}_{5}$ in $\mathrm{PhCl}$. When alkylmetals containing group 4 main-group metals such as $n-\mathrm{Bu}_{4} \mathrm{Sn}$ and $\mathrm{Et}_{3} \mathrm{SiH}$ were used as cocatalysts, the monomer was consumed quantitatively and polymer yields were over $70 \%$. Organometallics involving groups $1-3$ main-group metals such as $n$-BuLi and $\mathrm{Et}_{3} \mathrm{Al}$ were also effective to some extent in producing the polymer. Eventually, polymer yield and $[\eta]$ took the highest values when $\mathrm{Et}_{3} \mathrm{SiH}$ was employed as cocatalyst.

Table II. Solvent effects on the polymerization of $p-\mathrm{C}_{9} \mathrm{~F}_{17} \mathrm{ODPA}$ by $\mathrm{TaCl}_{5}-n-\mathrm{Bu}_{4} \mathrm{Sn}^{\mathrm{a}}$

\begin{tabular}{lcccc}
\hline \multirow{2}{*}{ Solvent } & \multicolumn{2}{c}{ Conversion } & & \multicolumn{2}{c}{ Polymer $^{\mathrm{b}}$} \\
\cline { 2 - 2 } \cline { 5 - 5 } & $\%$ & & Yield $/ \%$ & {$[\eta] / \mathrm{dl} \mathrm{g}^{-1 \mathrm{c}}$} \\
\hline Toluene & 100 & & 70 & 0.87 \\
$\mathrm{PhCl}$ & 100 & & 76 & 1.22 \\
$\mathrm{PhCF}_{3}$ & 88 & & 5 & \\
$m-\left(\mathrm{CF}_{3}\right)_{2} \mathrm{C}_{6} \mathrm{H}_{4}$ & 65 & & 18 & \\
$\mathrm{CCl}_{2} \mathrm{FCCl}_{2} \mathrm{~F}$ & 71 & & 42 & 0.45
\end{tabular}

a Polymerized at $80^{\circ} \mathrm{C}$ for $24 \mathrm{~h} ;[\mathrm{M}]_{0}=0.20 \mathrm{M}$, $\left[\mathrm{TaCl}_{5}\right]=20 \mathrm{mM},\left[n-\mathrm{Bu}_{4} \mathrm{Sn}\right]=40 \mathrm{mM}$.

b Acetone-insoluble part.

c Intrinsic viscosity measured in $m-\left(\mathrm{CF}_{3}\right)_{2} \mathrm{C}_{6} \mathrm{H}_{4}$ at $30^{\circ} \mathrm{C}$.
Figure 1 illustrates the effects of temperature on polymerization by $\mathrm{TaCl}_{5}-\mathrm{Et}_{3} \mathrm{SiH}$ in $\mathrm{PhCl}$. Polymer yield was above $70 \%$ in the range of $80-120^{\circ} \mathrm{C}$. $[\eta]$ of the polymer gradually decreased with increasing temperature. Thus, about $80^{\circ} \mathrm{C}$ seems favorable to keep both yield and $[\eta]$ of the polymer high.

The polymerization by $\mathrm{TaCl}_{5}-\mathrm{Et}_{3} \mathrm{SiH}$ was completed in 30 min under the conditions shown in Figure 2, being fairly rapid. [ $\eta]$ of the polymer stayed almost constant regardless of the polymer yield.

Effects of monomer and catalyst concentrations were studied (Table IV). Under the conditions used, polymer yields were $70-90 \%$. $[\eta]$ of the polymer increased with decreasing $[\mathrm{M}]_{0}$ when $[\mathrm{Cat}]=20 \mathrm{mM}$. Thus it seems that

Table III. Cocatalyst effects on the polymerization of $p-\mathrm{C}_{9} \mathrm{~F}_{17} \mathrm{ODPA}$ by $\mathrm{TaCl}_{5}{ }^{\mathrm{a}}$

\begin{tabular}{|c|c|c|c|c|}
\hline \multirow{2}{*}{ Run } & \multirow{2}{*}{ Cocatalyst } & \multirow{2}{*}{$\frac{\text { Conversion }}{\%}$} & \multicolumn{2}{|c|}{ Polymer ${ }^{b}$} \\
\hline & & & Yield $/ \%$ & {$[\eta] / \mathrm{dl} \mathrm{g}^{-1 \mathrm{c}}$} \\
\hline 1 & None & 56 & 0 & \\
\hline 2 & $n-\mathrm{Bu}_{4} \mathrm{Sn}$ & 100 & 76 & 1.22 \\
\hline 3 & $\mathrm{Et}_{3} \mathrm{SiH}$ & 100 & 85 & 1.60 \\
\hline 4 & $n$-BuLi & 80 & 56 & 1.41 \\
\hline 5 & $\mathrm{Et}_{3} \mathrm{Al}$ & 88 & 17 & \\
\hline
\end{tabular}

a Polymerized in $\mathrm{PhCl}$ at $80^{\circ} \mathrm{C}$ for $24 \mathrm{~h}$; $[\mathrm{M}]_{0}=0.20 \mathrm{M}$, $\left[\mathrm{TaCl}_{5}\right]=20 \mathrm{mM}$, [Cocat $]=40 \mathrm{mM}$.

b Acetone-insoluble part.

c Intrinsic viscosity measured in $m-\left(\mathrm{CF}_{3}\right)_{2} \mathrm{C}_{6} \mathrm{H}_{4}$ at $30^{\circ} \mathrm{C}$.

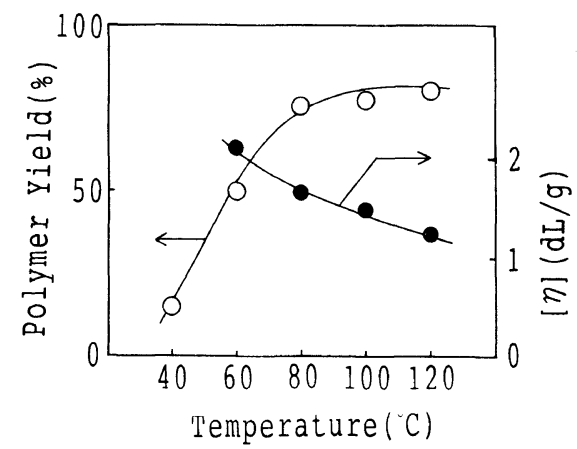

Figure 1. Temperature dependence of the polymerization of $p-\mathrm{C}_{9} \mathrm{~F}_{17} \mathrm{DPA}$ by $\mathrm{TaCl}_{5}-\mathrm{Et}_{3} \mathrm{SiH}$ (in $\mathrm{PhCl}, 24 \mathrm{~h}$, $[\mathrm{M}]_{0}=0.20 \mathrm{M},\left[\mathrm{TaCl}_{5}\right]=20 \mathrm{mM},\left[\mathrm{Et}_{3} \mathrm{SiH}\right]=40 \mathrm{mM}$ ), 


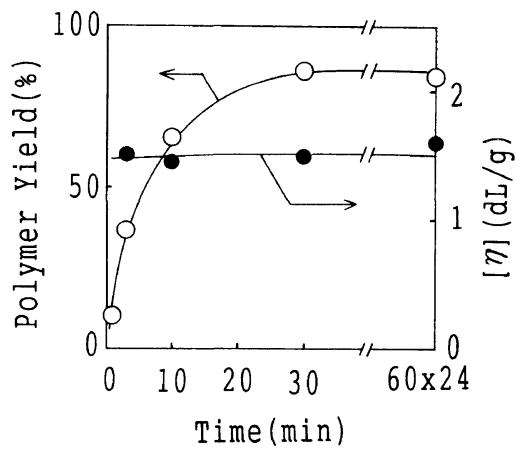

Figure 2. Time courses of the polymerization of $p$ $\mathrm{C}_{9} \mathrm{~F}_{17} \mathrm{DPA}$ by $\mathrm{TaCl}_{5}-\mathrm{Et}_{3} \mathrm{SiH}$ (in $\mathrm{PhCl}, 80^{\circ} \mathrm{C},[\mathrm{M}]_{0}=$ $0.20 \mathrm{M},\left[\mathrm{TaCl}_{5}\right]=20 \mathrm{mM},\left[\mathrm{Et}_{3} \mathrm{SiH}\right]=40 \mathrm{mM}$ ).

Table IV. Effects of monomer and catalyst concentrations on the polymerization of $p-\mathrm{C}_{9} \mathrm{~F}_{17} \mathrm{ODPA}$ by $\mathrm{TaCl}_{5}-\mathrm{Et}_{3} \mathrm{SiH}^{\mathrm{a}}$

\begin{tabular}{|c|c|c|c|c|c|}
\hline \multirow{2}{*}{ Run } & \multirow{2}{*}{$\frac{[\mathrm{M}]_{0}}{\mathrm{M}}$} & \multirow{2}{*}{$\frac{[\mathrm{Cat}]}{\mathrm{mM}}$} & \multirow{2}{*}{$\frac{\text { Conversion }}{\%}$} & \multicolumn{2}{|c|}{ Polymer $^{b}$} \\
\hline & & & & Yield $/ \%$ & {$[\eta] / \mathrm{dl} \mathrm{g}^{-1 \mathrm{c}}$} \\
\hline 1 & 0.10 & 20 & 100 & 88 & 2.10 \\
\hline 2 & 0.20 & 20 & 100 & 85 & 1.60 \\
\hline 3 & 0.50 & 20 & 100 & 79 & 1.05 \\
\hline 4 & 0.20 & 10 & 100 & 80 & 1.22 \\
\hline 5 & 0.20 & 5 & 100 & 72 & 1.30 \\
\hline
\end{tabular}

a Polymerized in $\mathrm{PhCl}$ at $80^{\circ} \mathrm{C}$ for $24 \mathrm{~h}$.

b Acetone-insoluble part.

c Intrinsic viscosity measured in $m-\left(\mathrm{CF}_{3}\right)_{2} \mathrm{C}_{6} \mathrm{H}_{4}$ at $30^{\circ} \mathrm{C}$.

lower monomer concentration $(0.1-0.2 \mathrm{M})$ is favorable to attain the high $[\eta]$. On the other hand, the decrease of catalyst concentration did not increase $[\eta]$.

The above results lead to the conclusion that the polymerization conditions in Table IV, run 1 or 2 are optimal to simultaneously achieve high yield and high molecular weight of $\operatorname{poly}\left(p-\mathrm{C}_{9} \mathrm{~F}_{17} \mathrm{ODPA}\right)$.

In order to clarify the influence of $p-\mathrm{C}_{9} \mathrm{~F}_{17} \mathrm{O}$ group on the relative monomer reactivity, $1: 1$ copolymerization of $p-\mathrm{C}_{9} \mathrm{~F}_{17} \mathrm{ODPA}$ with DPA was carried out (Figure 3). Both monomers were consumed at similar rates. In the copolymerization of substituted acetylenes, a general tendency has been observed that the monomer reactivity increases with decreasing

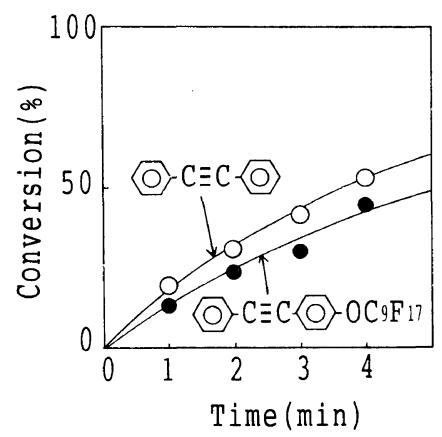

Figure 3. Copolymerization of $p-\mathrm{C}_{9} \mathrm{~F}_{17} \mathrm{DPA}$ with DPA by $\mathrm{TaCl}_{5}-\mathrm{Et}_{3} \mathrm{SiH}$ (in $\mathrm{PhCl}, 80^{\circ} \mathrm{C},\left[\mathrm{M}_{1}\right]_{0}=\left[\mathrm{M}_{2}\right]_{0}=0.10 \mathrm{M}$, $\left.\left[\mathrm{TaCl}_{5}\right]=20 \mathrm{mM},\left[\mathrm{Et}_{3} \mathrm{SiH}\right]=40 \mathrm{mM}\right)$.

Table V. Polymerization of $p-\mathrm{C}_{9} \mathrm{~F}_{17} \mathrm{OPH}$ by various catalysts ${ }^{\mathrm{a}}$

\begin{tabular}{lcccc}
\hline \multicolumn{1}{c}{ Catalyst } & Conversion & & \multicolumn{2}{c}{ Polymer $^{\mathrm{b}}$} \\
\cline { 2 - 2 } & $\%$ & & Yield $\%$ & {$[\eta] / \mathrm{dl} \mathrm{g}^{-1 \mathrm{c}}$} \\
\hline $\mathrm{TaCl}_{5}$ & 100 & & 4 & \\
$\mathrm{TaCl}_{5}-n-\mathrm{Bu}_{4} \mathrm{Sn}$ & 100 & & 54 & 0.23 \\
$\mathrm{NbCl}_{5}$ & 100 & & 13 & \\
$\mathrm{NbCl}_{5}-n-\mathrm{Bu}_{4} \mathrm{Sn}$ & 100 & & 55 & 0.25 \\
$\mathrm{WCl}_{6}-n-\mathrm{Bu}_{4} \mathrm{Sn}$ & 58 & & 7 & \\
$\mathrm{MoCl}_{5}-n-\mathrm{Bu}_{4} \mathrm{Sn}$ & 26 & & 0 &
\end{tabular}

a Polymerized in toluene at $80^{\circ} \mathrm{C}$ for $24 \mathrm{~h} ;[\mathrm{M}]_{0}=0.20$ $\mathrm{M},[\mathrm{Cat}]=\left[n-\mathrm{Bu}_{4} \mathrm{Sn}\right]=20 \mathrm{mM}$.

b Acetone-insoluble part.

c Intrincis viscosity measured in $m-\left(\mathrm{CF}_{3}\right)_{2} \mathrm{C}_{6} \mathrm{H}_{4}$ at $30^{\circ} \mathrm{C}$.

bulkiness of substituent and with increasing electron-donating ability of substituent. ${ }^{15,16}$ Thus, the results of the present study indicate that the $p-\mathrm{C}_{9} \mathrm{~F}_{17} \mathrm{O}$ group hardly affects monomer reactivity either sterically or electronically.

\section{Polymerization of $p-\mathrm{C}_{9} \mathrm{~F}_{17} \mathrm{OPH}$}

Polymerization of $p-\mathrm{C}_{9} \mathrm{~F}_{17} \mathrm{OPH}$ was examined using various catalysts (Table V). $\mathrm{TaCl}_{5}$ and $\mathrm{NbCl}_{5}$ alone, which polymerized 1-phenyl-1-alkynes in high yields, ${ }^{5}$ afforded poly $\left(p-\mathrm{C}_{9} \mathrm{~F}_{17} \mathrm{OPH}\right)$ in rather low yields. The acetone-soluble product was a mixture of linear oligomers and cyclotrimers (acetone, which dissolved cyclotrimers of $p-\mathrm{C}_{9} \mathrm{~F}_{17} \mathrm{OPH}$, was 
Table VI. Solvent effects on the polymerization of $p-\mathrm{C}_{9} \mathrm{~F}_{17} \mathrm{OPH}$ by $\mathrm{TaCl}_{5}-n-\mathrm{Bu}_{4} \mathrm{Sn}$ and $\mathrm{NbCl}_{5}-n-\mathrm{Bu}_{4} \mathrm{Sn}^{\mathrm{a}}$

Run Solvent $\frac{\text { Conversion }}{\%} \frac{\text { Polymer }^{\mathrm{b}}}{\text { Yield } / \%[\eta] / \mathrm{dl} \mathrm{g}^{-1 \mathrm{c}}}$

\begin{tabular}{llrrr}
\hline \multicolumn{5}{c}{$\mathrm{TaCl}_{5}-n-\mathrm{Bu}_{4} \mathrm{Sn}$ catalyst } \\
1 & Toluene & 100 & 54 & 0.23 \\
2 & $\mathrm{PhCl}$ & 97 & 50 & 0.35 \\
3 & $m-\left(\mathrm{CF}_{3}\right)_{2} \mathrm{C}_{6} \mathrm{H}_{4}$ & 95 & 6 & \\
4 & $\mathrm{CCl}_{2} \mathrm{FCCl}_{2} \mathrm{~F}$ & 98 & 55 & 0.67 \\
\multicolumn{4}{r}{$\mathrm{NbCl}_{5}-n-\mathrm{Bu}_{4} \mathrm{Sn}$ catalyst } \\
5 & Toluene & 96 & 55 & 0.25 \\
6 & $\mathrm{PhCl}_{7}$ & 72 & 58 & 0.40 \\
8 & $m-\left(\mathrm{CF}_{3}\right)_{2} \mathrm{C}_{6} \mathrm{H}_{4}$ & 91 & 4 & \\
& $\mathrm{CCl}_{2} \mathrm{FCCl}_{2} \mathrm{~F}$ & 97 & 61 & 0.51 \\
\hline
\end{tabular}

a Polymerized at $80^{\circ} \mathrm{C}$ for $24 \mathrm{~h} ;[\mathrm{M}]_{0}=0.20 \mathrm{M},\left[\mathrm{TaCl}_{5}\right]=$ $\left[n-\mathrm{Bu}_{4} \mathrm{Sn}\right]=20 \mathrm{mM}$.

b Acetone-insoluble part.

c Intrinscis viscosity measured in $m-\left(\mathrm{CF}_{3}\right)_{2} \mathrm{C}_{6} \mathrm{H}_{4}$ at $30^{\circ} \mathrm{C}$.

adopted as precipitant). Use of equimolar $n$ - $\mathrm{Bu}_{4} \mathrm{Sn}$ as cocatalyst, which is effective for increasing molecular weight of poly(1-phenyl1-alkynes $),{ }^{6}$ gave poly $\left(p-\mathrm{C}_{9} \mathrm{~F}_{17} \mathrm{OPH}\right)$ in $c a$. $50 \%$ yield, and $[\eta]$ was about $0.2 \mathrm{dlg}^{-1}$. $\mathrm{WCl}_{6}-n-\mathrm{Bu}_{4} \mathrm{Sn}$, and $\mathrm{MoCl}_{5}-n-\mathrm{Bu}_{4} \mathrm{Sn}$, on the other hand, hardly gave acetone-insoluble products.

Solvent effects on the polymerization by $\mathrm{TaCl}_{5}-n-\mathrm{Bu}_{4} \mathrm{Sn}$ and $\mathrm{NbCl}_{5}-n-\mathrm{Bu}_{4} \mathrm{Sn}$ were studied (Table VI). Interestingly, $[\eta]$ of the polymer considerably increased when polymerization was carried out in $\mathrm{CCl}_{2} \mathrm{FCCl}_{2} \mathrm{~F}$. Such a tendency was not seen in the polymerization of $p-\mathrm{C}_{9} \mathrm{~F}_{17} \mathrm{ODPA}$. $\mathrm{PhCl}$ was effective to some extent in inceasing $[\eta]$ of $\operatorname{poly}\left(p-\mathrm{C}_{9} \mathrm{~F}_{17} \mathrm{ODPA}\right.$ ) (see above).

As seen in Table VII, polymer yield was affected by the kind of cocatalyst. The yield was relatively high when $n-\mathrm{Bu}_{4} \mathrm{Sn}$ or $\mathrm{Et}_{3} \mathrm{SiH}$ was used, whereas $n$-BuLi hardly produced the polymer.

Consequently, both yield and $[\eta]$ of $\operatorname{poly}\left(p-\mathrm{C}_{9} \mathrm{~F}_{17} \mathrm{OPH}\right)$ were considerably lower than those of poly $\left(p-\mathrm{C}_{9} \mathrm{~F}_{17} \mathrm{ODPA}\right)$, irrespec-
Table VII. Cocatalyst effects on the polymerization of $p-\mathrm{C}_{9} \mathrm{~F}_{17} \mathrm{OPH}$ by $\mathrm{TaCl}_{5}$ and $\mathrm{NbCl}_{5}{ }^{\mathrm{a}}$

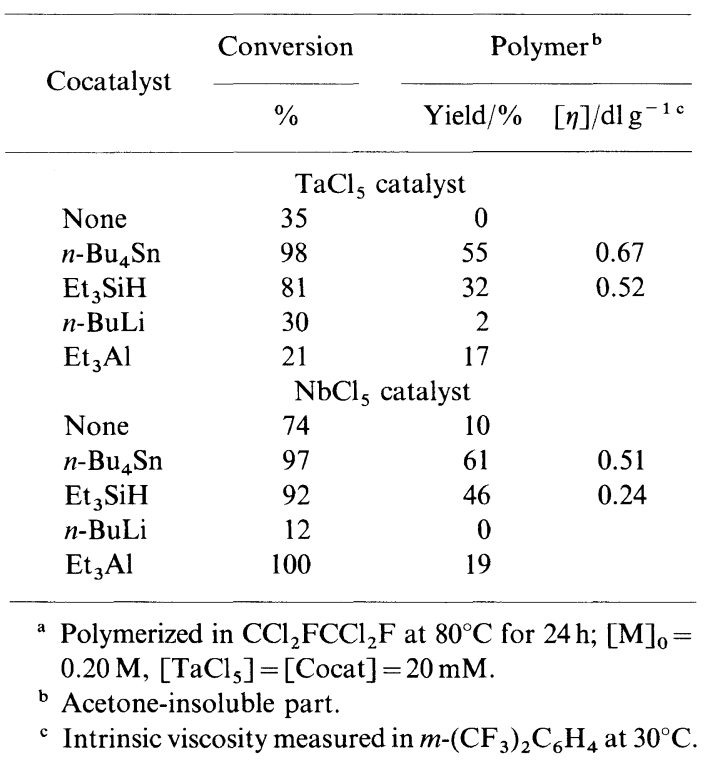

tive of polymerization conditions.

\section{Polymer Structure}

Analytical data of poly $\left(p-\mathrm{C}_{9} \mathrm{~F}_{17} \mathrm{ODPA}\right)$ and poly $\left(p-\mathrm{C}_{9} \mathrm{~F}_{17} \mathrm{OPH}\right)$ did not depend on the polymerization conditions. The data stated below were obtained with the polymer samples from Table III, run 3 and Table VI, run 4.

Elemental analysis data of poly $\left(p-\mathrm{C}_{9} \mathrm{~F}_{17} \mathrm{OD}\right.$ PA) and poly $\left(p-\mathrm{C}_{9} \mathrm{~F}_{17} \mathrm{OPH}\right)$ agreed well with theoretical values; Anal. $\mathrm{Poly}\left(p-\mathrm{C}_{9} \mathrm{~F}_{17} \mathrm{ODPA}\right)$ : Calcd for $\left(\mathrm{C}_{23} \mathrm{H}_{9} \mathrm{~F}_{17} \mathrm{O}\right)_{\mathrm{n}}$ : C, $44.2 \% ; \mathrm{H}, 1.5 \%$; F, $51.7 \%$; O, 2.6\%. Found: C, 43.5\%; H, 1.3\%; F, 52.0\%; O, 2.8\%. Poly $\left(p-\mathrm{C}_{9} \mathrm{~F}_{17} \mathrm{OPH}\right):$ Calcd for $\left(\mathrm{C}_{21} \mathrm{H}_{13} \mathrm{~F}_{17} \mathrm{O}\right)_{\mathrm{n}}$ : C, 41.7\%; H, 2.2\%; F, $53.4 \% ; \mathrm{O}, 2.7 \%$. Found: $\mathrm{C}, 42.2 \% ; \mathrm{H}, 1.4 \%$; F, $52.5 \%$; O, $2.0 \%$.

As seen from Figure 4, the IR spectra of $\operatorname{poly}\left(p-\mathrm{C}_{9} \mathrm{~F}_{17} \mathrm{ODPA}\right)$ and $\operatorname{poly}\left(p-\mathrm{C}_{9} \mathrm{~F}_{17} \mathrm{OPH}\right)$ do not show absorption due to $\mathrm{C} \equiv \mathrm{C}$ stretching which was observed at $2220 \mathrm{~cm}^{-1}$ with the monomers. Strong absorptions characteristic of $\mathrm{C}-\mathrm{F}$ stretching were seen at $1300-1200$ $\mathrm{cm}^{-1}$ in both monomers and polymers.

${ }^{13} \mathrm{C}$ NMR spectra of monomers showed two 


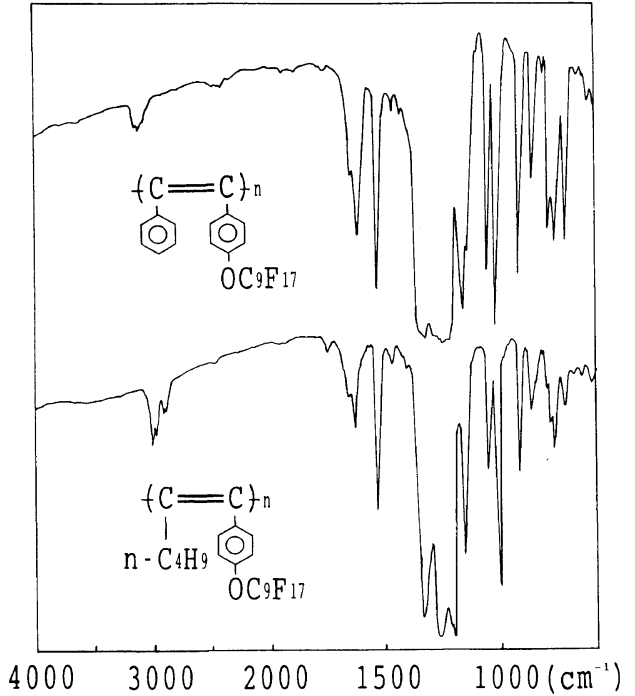

Figure 4. IR spectra of $\operatorname{poly}\left(p-\mathrm{C}_{9} \mathrm{~F}_{17} \mathrm{DPA}\right)$ and $\operatorname{poly}(p-$ $\left.\mathrm{C}_{9} \mathrm{~F}_{17} \mathrm{PH}\right)(\mathrm{KBr}$ pellet; samples from Table III, run 3 and Table VI, run 4).

peaks due to two acetylenic carbons at $\delta 87.7$ and 90.1 ( $\left.p-\mathrm{C}_{9} \mathrm{~F}_{17} \mathrm{ODPA}\right)$, and at $\delta 79.1$ and $91.2\left(p-\mathrm{C}_{9} \mathrm{~F}_{17} \mathrm{OPH}\right)$, which disappeared in the polymers.

The IR and ${ }^{13} \mathrm{C}$ NMR spectra thus support the idea that the polymers possess alternating double bonds in the main chain as shown in Figure 4. No information about the geometric structure of the main chain, however, could be obtained from these spectra.

In the UV-visible spectra of $\operatorname{poly}(p$ $\left.\mathrm{C}_{9} \mathrm{~F}_{17} \mathrm{ODPA}\right)$ and poly $\left(p-\mathrm{C}_{9} \mathrm{~F}_{17} \mathrm{OPH}\right)$, absorptions continue up to $c a .500 \mathrm{~nm}$ and $c a$. $400 \mathrm{~nm}$, respectively. $\operatorname{Poly}\left(p-\mathrm{C}_{9} \mathrm{~F}_{17} \mathrm{ODPA}\right)$ has an absorption maximum at $420 \mathrm{~nm}\left(\varepsilon_{\max }\right.$ $\left.5400 \mathrm{M}^{-1} \mathrm{~cm}^{-1}\right)$. These spectra suggest that the extent of conjugation of alternating double bonds is not very high; that is, the main chain is considerably twisted.

\section{Polymer Properties}

$\operatorname{Poly}\left(p-\mathrm{C}_{9} \mathrm{~F}_{17} \mathrm{ODPA}\right)$ and $\operatorname{poly}\left(p-\mathrm{C}_{9} \mathrm{~F}_{17^{-}}\right.$ $\mathrm{OPH})$ have the form of a yellow solid and white solid, respectively, irrespective of polymerization conditions. Other properties of the poly-

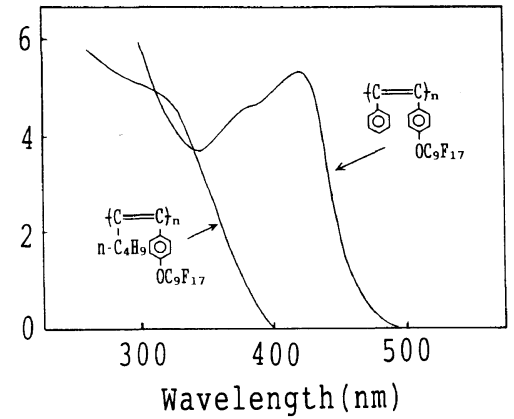

Figure 5. UV-visible spectra of poly $\left(p-\mathrm{C}_{9} \mathrm{~F}_{17} \mathrm{DPA}\right)$ and poly $\left(p-\mathrm{C}_{9} \mathrm{~F}_{17} \mathrm{PH}\right)\left(\mathrm{CCl}_{2} \mathrm{FCClF}{ }_{2}\right.$ solution; samples from Table III, run 3 and Table VI, run 4).

mers were also independent of the polymerization conditions; the samples used are from Table III, run 3 and Table VI, run 4.

$\operatorname{Poly}\left(p-\mathrm{C}_{9} \mathrm{~F}_{17} \mathrm{ODPA}\right)$ and $\operatorname{poly}\left(p-\mathrm{C}_{9} \mathrm{~F}_{17^{-}}\right.$ $\mathrm{OPH})$ completely disssolved in some fluorinecontaining solvents such as $m-\left(\mathrm{CF}_{3}\right)_{2} \mathrm{C}_{6} \mathrm{H}_{4}$, and $\mathrm{CCl}_{2} \mathrm{FCClF}_{2}$, and partly dissolved in $\mathrm{CCl}_{2} \mathrm{FCCl}_{2} \mathrm{~F}$ and hexafluoropropene trimers. Their nonsolvents include benzene, toluene, $\mathrm{PhCl}$, cyclohexane, $\mathrm{CHCl}_{3}$, and tetrahydrofuran (THF). In general, polymers from symmetrically disubstituted acetylenes are insoluble in any solvent. For example, poly(1phenyl-1-propyne $)^{5}$ and poly(3-octyne $)^{17}$ are soluble in common organic solvents whereas poly(DPA $)^{4}$ and poly(4-octyne $)^{17}$ are not. The very poor solubility of poly $(\mathrm{PH})$ is considered to be related to the above tendency. ${ }^{5}$ The introduction of bulky $\mathrm{C}_{9} \mathrm{~F}_{17} \mathrm{O}$ group, therefore, has proved effective in making substituents unsymmetrical to convert insoluble poly(DPA) and poly (PH) into soluble polymers. In this connection, it has recently been revealed that poly(DPA)s containing trimethylsilyl group on one phenyl group are totally soluble in common organic solvents. ${ }^{18}$

A tough, free-standing film is accessible from poly $\left(p-\mathrm{C}_{9} \mathrm{~F}_{17} \mathrm{ODPA}\right)$ by casting its $m-\left(\mathrm{CF}_{3}\right)_{2}$ $\mathrm{C}_{6} \mathrm{H}_{4}$ solution. Poly $\left(p-\mathrm{C}_{9} \mathrm{~F}_{17} \mathrm{OPH}\right)$ is too brittle to hold its filmy state, which is probably due to its molecular weight being not high enough. 


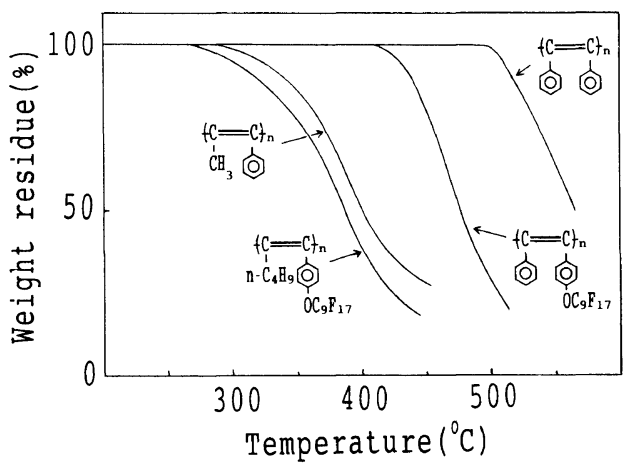

Figure 6. Thermogravimetric analysis of poly $\left(p-\mathrm{C}_{9} \mathrm{~F}_{17^{-}}\right.$ DPA) and poly $\left(p-\mathrm{C}_{9} \mathrm{~F}_{17} \mathrm{PH}\right)$ (in air, heating rate $10^{\circ} \mathrm{C}$ $\min ^{-1}$; samples from Table III, run 3 and Table VI, run 4).

The surface wettability of poly $\left(p-\mathrm{C}_{9} \mathrm{~F}_{17} \mathrm{OD}\right.$ PA) film was evaluated by measuring the contact angles of water and $n$-decane on the film. The contact angles were $115^{\circ}$ (water) and $30^{\circ}$ ( $n$-decane), respectively. These values are close to those for poly(tetrafluoroethylene) ${ }^{19}$ $\left[108^{\circ}\right.$ (water) and $35^{\circ}$ ( $n$-decane) $]$, indicating the low surface energy of poly $\left(p-\mathrm{C}_{9} \mathrm{~F}_{17} \mathrm{ODPA}\right)$.

Poly $\left(p-\mathrm{C}_{9} \mathrm{~F}_{17} \mathrm{ODPA}\right)$ began to lose weight at about $410^{\circ} \mathrm{C}$, in TGA in air (Figure 6). Though this temperature is more or less lower than that of poly(DPA) $\left(500^{\circ} \mathrm{C}\right)$, it is higher than those of most substituted polyacetylenes such as poly(1-phenyl-1-propyne $)^{5}\left(280^{\circ} \mathrm{C}\right)$. The weight loss of poly $\left(p-\mathrm{C}_{9} \mathrm{~F}_{17} \mathrm{OPH}\right)$ occurs at $270^{\circ} \mathrm{C}$, being comparable to that of poly(1-phenyl-1-propyne). Further, none of the present polymers suffers any molecular weight decrease or oxidation even though they are left in air either at $120^{\circ} \mathrm{C}$ for $20 \mathrm{~h}$ or at room temperature over a few months. Thus the present polymers possess high thermal stability.

Poly $\left(p-\mathrm{C}_{9} \mathrm{~F}_{17} \mathrm{ODPA}\right)$ did not soften below $400^{\circ} \mathrm{C}$, reflecting its stiff backbone due to the presence of two bulky rigid phenyl groups. On the other hand, the softening point of $\operatorname{poly}\left(p-\mathrm{C}_{9} \mathrm{~F}_{17} \mathrm{OPH}\right)$ was about $250^{\circ} \mathrm{C}$, which is somewhat lower than those of poly(1-phenyl1-alkynes) $\left(260-300^{\circ} \mathrm{C}\right) .^{5}$

The mechanical properties of $\operatorname{poly}\left(p-\mathrm{C}_{9} \mathrm{~F}_{17^{-}}\right.$ ODPA) are as follows: Young's modulus
$1100 \mathrm{MPa}$, tensile strength $15 \mathrm{MPa}$, elongation at break $1.6 \%$ at $25^{\circ} \mathrm{C}$. These data show that poly $\left(p-\mathrm{C}_{9} \mathrm{~F}_{17} \mathrm{ODPA}\right)$ is hard and rather brittle.

The oxygen permeability coefficient $\left(P_{\mathrm{O}_{2}}\right)$ of a poly $\left(p-\mathrm{C}_{9} \mathrm{~F}_{17} \mathrm{ODPA}\right)$ membrane at $25^{\circ} \mathrm{C}$ was ca. $4 \times 10^{-8} \mathrm{~cm}^{3}$ (STP) $\mathrm{cm} \mathrm{cm}^{-2} \mathrm{~s}^{-1} \mathrm{~cm} \mathrm{Hg}^{-1}$, and the separation factor of oxygen and nitrogen $\left(P_{\mathrm{O}_{2}} / P_{\mathrm{N}_{2}}\right)$ was 1.8 . This $P_{\mathrm{O}_{2}}$ is comparable with that of poly(dimethylsiloxane) $\left[6 \times 10^{-8} \mathrm{~cm}^{3}(\mathrm{STP}) \mathrm{cm} \mathrm{cm}^{-2} \mathrm{~s}^{-1} \mathrm{~cm} \mathrm{Hg}^{-1}\right]$, being fairly large among those of glassy polymers.

Acknowledgments. The authors thank Professor T. Higashimura and Professor T. Masuda, Kyoto University, for valuable discussion and kind advice. Thanks are also due to Mr. K. Shiro for measurement of gas permeability.

\section{REFERENCES}

1. T. Masuda and T. Higashimura, Adv. Polym. Sci., 81, 121 (1986).

2. G. Costa, in "Comprehensive Polymer Science," Vol. 4, G. Allen, Ed., Pergamon, New York, 1989, Chapter 9.

3. T. Masuda, B.-Z. Tang, T. Higashimura, and H. Yamaoka, Macromolecules, 18, 2369 (1985).

4. A. Niki, T. Masuda, and T. Higashimura, J. Polym. Sci., Polym. Chem. Ed., 25, 1553 (1987).

5. T. Masuda, T. Takahashi, and T. Higashimura, Macromolecules, 18, 311 (1985).

6. T. Masuda, A. Niki, E. Isobe, and T. Higashimura, Macromolecules, 18, 2109 (1985).

7. K. Tsuchihara, T. Masuda, and T. Higashimura, Polym. Bull., 20, 343 (1988).

8. H. Muramatsu, T. Ueda, and K. Ito, Macromolecules, 18, 1634 (1985).

9. T. Masuda, T. Hamano, T. Higashimura, T. Ueda, and H. Muramatsu, Macromolecules, 21, 281 (1988).

10. K. Tsuchihara, T. Masuda, T. Higashimura, M. Nishida, and H. Muramatsu, Polym. Bull., 23, 505 (1990).

11. T. Yoshimura, T. Masuda, T. Higashimura, K. Okuhara, and T. Ueda, Macromolecules, 24, 6053 (1991).

12. T. Yoshimura, T. Masuda, T. Higashimura, and T. Ishihara, J. Polym. Sci., Polym. Chem. Ed., 24, 3569 (1986).

13. S. Sasaki and K. Nakamura, J. Polym. Sci., Polym. Chem. Ed., 22, 831 (1984). 


\section{Fluorine-Containing Polyacetylenes}

14. K. Tsuchihara, T. Oshita, T. Masuda, and T. 17. T. Masuda, Y. Kuwane, and T. Higashimura, Polym. Higashimura, Polym. J., 23, 1273 (1991).

J., 13, 301 (1981).

15. K. Hasegawa, T. Masuda, and T. Higashimura, 18. K. Tsuchihara, T. Masuda, and T. Higashimura, $J$. Macromolecules, 8, 255 (1975).

16. T. Hamano, T. Masuda, and T. Higashimura, $J$. Polym. Sci., Polym. Chem. Ed., 26, 2603 (1988). Am. Chem. Soc., 113, 8548 (1991).

19. H. W. Fox and W. A. Zisman, J. Colloid Sci., 5, 514 (1950). 